\title{
INCREASING POETRY WRITING SKILLS THROUGH MEDIA COLLECTION OF PANDEMI THEMES OF SHORT FILM ON STUDENTS CLASS 1 STATE 1 SMA KRIAN SIDOARJO
}

\section{PENINGKATAN KETERAMPILAN MENULIS PUISI MELALUI MEDIA KUMPULAN FILM PENDEK BERTEMA PANDEMI PADA SISWA KELAS 1 SMA NEGERI 1 KRIAN SIDOARJO}

\author{
M.A. Haris Firismanda \\ Magister Kaajian Sastra dan Budaya FIB Universitas Airlangga \\ e-mail : m.a.haris.firismanda-2021@fib.unair-ac.id \\ DOI: https://doi.org/10.52048/inovasi.v15i1.245
}

\begin{abstract}
This study aimed to improve students' ability in writing poetry through the medium of short film collection with a pandemic theme. The subjects of this study were the First grade students of SMA Negeri 1 Krian Sidoarjo. This research uses Classroom Action Research (CAR). The results showed that the poetry writing skills of the First grade students of SMA Negeri 1 Krian, Sidoarjo district, had increased. In preliminary study, it was identified that the students' poetry writing skills reached a complete level of $34.61 \%$ and an incomplete level of $65.38 \%$. Then, after conducting two cycles, the first cycle reached the level of completion $42.30 \%$ and the level of incompleteness $57.69 \%$. Meanwhile, the second cycle indicated $76.92 \%$ level of completion and $23.07 \%$ level of incomplete. The findings of this study are that the medium of a collection of short films with the theme of a pandemic can improve poetry a wraiting skills. In conclusion, learning to write poetry through a collection of short films with the theme of pandemic is helpful for students of language class in SMAN 1 Krian Sidoarjo. It could increase their ability in writing poetry. Thus, the researcher suggest the teacher to choose varied learning media in order to enhance their students'poetry writing skill.
\end{abstract}

Keywords : Improvement, poetry, films media.

\begin{abstract}
ABSTRAK
Penelitian ini bertujuan untuk meningkatkan keterampilan menulis puisi melalui media kumpulan film pendek bertema pandemi pada siswa kelas 1 Bahasa SMA Negeri 1 Krian Sidoarjo. Penelitian ini menggunakan penelitian tindakan kelas (PTK). Hasil penelitian menunjukkan keterampilan menulis puisi siswa kelas 1 Bahasa SMA Negeri 1 Krian kabupaten Sidoarjo mengalami peningkatan. Data hasil identifikasi awal berupa studi pendahuluan keterampilan menulis puisi siswa mencapai tingkat tuntas sebesar 34,61 \% dan tingkat tidak tuntas sebesar 65,38\%. Kemudian, setelah implementasi pembelajaran melalui media kumpulan film pendek bertema pandemi hasil keterampilan menulis puisi siswa pada siklus I mencapai tingkat tuntas sebesar 42,30\%, sedangkan pada tingkat tidak tuntas sebesar 57,69\%. Pada siklus II mencapai tingkat tuntas sebesar 76,92\%, sedangkan pada tingkat tidak tuntas sebesar $23,07 \%$. Temuan penelitian ini adalah media kumpulan film pendek bertema pandemi dapat meningkatkan keterampilan menulis puisi. Kesimpulannya pembelajaran menulis puisi melalui media kumpulan film pendek bertema pandemi dapat meningkatkan keterampilan menulis puisi pada siswa kelas 1 Bahasa SMAN 1 Krian Sidoarjo. Oleh karena itu, saran peneliti hendaknya guru mampu memilih media pembelajaran yang bervariatif dalam upaya meningkatkan keterampilan menulis puisi siswa.
\end{abstract}

Kata Kunci: Peningkatan, puisi, Media Film. 


\section{PENDAHULUAN}

Keterampilan menulis merupakan salah satu keterampilan berbahasa yang penting untuk dimiliki siswa. Dengan keterampilan tersebut siswa dapat mencurahkan perasaannya melalui tulisan, misalnya dalam bentuk puisi.

Dalam teori bahasa terdapat empat keterampilan berbahasa yang secara umum harus dikuasai oleh siswa. Keempat keterampilan itu ialah: keterampilan membaca, menulis, menyimak, dan berbicara. Namun, dari keempat keterampilan tersebut, hanya keterampilan menulis yang memerlukan keahlian khusus. Oleh karena itu, keterampilan tersebut perlu ditanamkan sejak dini.

Dalam kurikulum nasional, keterampilan menulis dianggap sebagai suatu kegiatan berbahasa yang bersifat aktif dan produktif. Yang dimaksud dengan aktif adalah keterampilan menulis menuntut adanya kegiatan menyampaikan pesan kepada orang lain melalui bahasa tulis, sedangkan yang dimaksud produktif adalah kegiatan menulis bertujuan untuk menyampaikan gagasan, pikiran, atau perasaan penutur.

Sejalan dengan kurikulum tersebut pembelajarana menulis puisi perlu mendapatkan perhatian. Namun, fenomena di lapangan pembelajaran keterampilan menulis puisi masih dianggap biasa sebagaimana guru mengajarkan keterampilan berbahasa lainnya. Demikian pula guru yang mengajarkan bidang sastra (puisi) masih dipegang oleh guru Bahasa Indonesia secara umum, dan bukan guru yang benarbenar memiliki kompetensi bidang sastra. Oleh karena itu, terkadang hasil yang diharapkan dari pembelajaran tersebut masih jauh dari kenyataan.

Melihat hal tersebut, banyak masyarakat dan para pemerhati sastra yang kecewa dengan hasil pembelajaran sastra secara umum. Para sastrawan pun mengeluh terhadap hasil yang dicapai oleh para guru di lapangan (Warsiman, 2017 : 5). Bahkan, beberapa tahun terakhir banyak para sastrawan yang turun gunung membantu para guru/praktisi memperkenalkan sastra dan mengingatkan pentingnya membekali anak wawasan tentang sastra yang memadai
(Warsiman, $2016: 7$ ).

Masa pandemi ini menjadi tantangan tersendiri bagi para guru, terutama guru-guru yang terlibat dalam pembelajaran sastra. Selain kurangnya pemberian media yang menarik, siswa juga dibebani oleh tugas-tugas sekolah yang cukup banyak. Hal demikian dapat mempengaruhi psikologi siswa. Oleh karena itu, guru perlu memanfaatkan media yang menarik bagi siswa agar mereka terdorong untuk belajar menulis puisi. Penggunaan media yang menarik dapat menjadi daya tarik siswa untuk terlibat secara aktif dalam pembelajaran menulis puisi. Pemberian stimulus seperti itu dapat memberikan keuntungan tersendiri bagi pembelajaran (Elisa, $2017: 104)$.

Peneliti menganggap situasi demikian justru guru harus berupaya untuk membangkitkan semangat siswa. Banyak cara yang bisa dilakukan. Guru dapat memanfaatkan teknologi dan ilmu pengetahuan yang berkembang dewasa ini. Hal itu dapat kita lihat di dalam media internet, hampir setiap waktu dijumpai hasilhasil aktivitas dan kreativitas orang. Mulai unggahan youtube, film pendek, vlog, dan lainlain. Pendek kata, pandemi bukan halangan kita untuk meraih pencapaian pembelajaran yang efektif (Hidayati, 2021: 58-59).

Hasil wawancara langsung dalam kunjungan di sekolah mitra, maupun melalui zoom meeting dengan guru Bahasa Indonesia dan kepala sekolah, diperoleh informasi bahwa keterampilan menulis puisi siswa kelas 1 Bahasa SMA Negeri 1 Krian kabupaten Sidoarjo secara umum masih rendah. Oleh karena itu, peneliti bersama guru mitra bersepakat untuk meningkatkan keterampilan tersebut melalui media kumpulan film pendek bertema pandemi.

Berdasarkan paparan tersebut maka permasalahan penelitian ini adalah: 1] bagaimana pelaksanaan pembelajaran keterampilan menulis puisi melalui media kumpulan film pendek bertema pandemi pada siswa kelas 1 Bahasa SMA Negeri 1 Krian kabupaten Sidoarjo; dan 2] bagaimana hasil pembelajaran keterampilan menulis puisi melalui media kumpulan film pendek bertema pandemi pada siswa kelas 1 Bahasa SMA Negeri 
1 Krian kabupaten Sidoarjo. Adapun tujuan penelitian ini adalah: 1] untuk mendeskripsikan pelaksanaan pembelajaran keterampilan menulis puisi melalui media kumpulan film pendek bertema pandemi pada siswa kelas 1 Bahasa SMA Negeri 1 Krian kabupaten Sidoarjo; dan 2] untuk mendeskripsikan hasil pembelajaran keterampilan menulis puisi melalui media kumpulan film pendek bertema pandemi pada siswa kelas 1 Bahasa SMA Negeri 1 Krian kabupaten Sidoarjo.

Sementara itu, manfaat yang diharapkan dari penelitian ini secara teoretis adalah dapat mengembangkan wawasan keilmuan dalam bidang pembelajaran sastra khususnya menulis puisi, sedangkan manfaat praktisnya: 1] bagi siswa, untuk memudahkan siswa belajar menulis puisi, 2] bagi guru, sebagai alternatif media pembelajaran yang dapat memperbaiki dan meningkatkan keterampilan menulis puisi, 3] bagi kepala sekolah, dapat menjadi masukan dalam rangka menetapkan kebijakan yang terkait dengan teknis pembelajaran untuk memperbaiki dan meningkatkan sistem pembelajaran di sekolah, dan 4] bagi peneliti, dapat menjadi bagian rujukan dalam melakukan penelitian lebih lanjut.

\section{KAJ IAN TEORI \\ Karakteristik Puisi}

Puisi merupakan karya sastra yang memiliki ciri khusus dan berbeda dengan prosa maupun drama (Waluyo, $1995: 3$ ). Perbedaan yang mencolok terletak pada tipografik dan struktur tematiknya. Puisi memiliki tipografi baris putusputus yang tidak membentuk kesatuan sintaksis. Dalam baris-baris puisi, kesenyapan antara baris satu dengan baris yang lain dapat memberikan petunjuk kuatnya bahasa yang dipilih. Yang terlihat nyata adalah adanya enjabemen (perloncatan kesatuan sintaksis ke baris lain). Enjabemen fungsinya untuk menonjolkan pikiran secara ekspresif. Itulah sebabnya ejabemen sering dipergunakan untuk menimbulkan tafsir ganda. Hal itu justru dapat memperkaya isi puisi. Di samping itu, struktur puisi membentuk tipografi yang khas. Larik-lariknya itu membentuk bait, dan bait-bait membentuk keseluruhan puisi.

Puisi dibentuk oleh dua unsur pokok, yaitu struktur lahir berupa bahasa yang digunakan meliputi: diksi, majas, rima, imajinasi, kata konkret, dan tipografi, dan struktur batin yaitu pikiran dan perasaan yang diungkapkan oleh penyair, melekat membentuk warna puisi meliputi: tema, nada, perasaan, dan amanat/ pesan (Waluyo, 1995 : 4). Keduanya merupakan kesatuan yang bertemali secara fungsional.

Struktur batin: 1] tema, dalam struktur batin tema merupakan gagasan pokok yang diungkapkan oleh penyair. Tema bisa mendesak relung hati penyair untuk menjadikannya sebagai landasan karyanya. Jika penyair berhubungan dengan Tuhan maka puisi tersebut akan bertemakan ketuhanan, jika penyair mendapati ketidakadilan maka puisi tersebut akan bertema kesenjangan, dan sebagainya; 2] nada atau suasana merupakan bentuk sikap penyair terhadap pembaca. Apakah penyair ingin menasihati, menyindir, mengejek, maupun menggurui; 3] perasaan merupakan ciri pembeda hasil karya penyair. Walaupun kedua penyair menulis karya yang bertema sama, tetapi kedua penyair tersebut memiliki perbedaan perasaan; 4] amanat/pesan merupakan sesuatu yang ingin disampaikan oleh penyair. Dengan amanat/pesan inilah penyair mampu mewujudkan karyanya.

Struktur lahir: 1] diksi, dalam struktur lahir diksi merupakan ketepatan pemilihan kata. Seorang penyair akan dengan cermat memilih kata-kata atau diksi yang ditulis, sebab keberadaan diksi bertemali dengan makna, rima, dan irama. Oleh karena itu, seorang penyair harus memilih kata yang tepat dengan mempertimbangkan urutan dan kekuatan/daya magis dari kata-kata tersebut; 2] majas, majas yang sering disebut pula dengan bahasa figuratif merupakan unsur penting dalam menulis puisi. Penyair sering menggunakan bahasa yang tersusun-susun atau berpigura, sehingga disebut figuratif. Bahasa figuratif dalam puisi menciptakan dampak prismatik artinya mampu memancarkan banyak makna atau dengan kata lain kaya akan makna. Dengan 
bahasa figuratiflah penyair mengatakan sesuatu dengan bahasa yang tidak biasa, yakni tidak langsung mengungkapkan makna; 3] rima, rima adalah pengulangan bunyi dalam puisi yang bisa membentuk musikalitas atau orkestrasi (Waluyo, 1995 : 90). Dalam puisi, rima muncul pada setiap akhir baris secara berulang-ulang dan teratur, sehingga membuat puisi menjadi merdu jika dibaca. Biasanya penyair akan mempertimbangkan lambang bunyi, sebab pemilihan bunyi dapat mendukung perasaan dan suasana puisi; 4] imajinasi, imajinasi sangat erat berhubungan dengan diksi dan kata konkret. Seorang penyair ketika memilih kata harus menghasilkan imajinasi. Dengan ketepatan memilih kata, maka bahasa puisi akan lebih konkret dapat dihayati dan seakan-akan pembaca merasakan dampak nyata seperti melihat, mendengar dan merasakan langsung; 5] kata konkret, kata konkret dibutuhkan dalam penulisan puisi dimaksudkan untuk membangkitkan imajinasi. Penyair yang hebat ia akan mampu membuat pembaca seolah-olah melihat, mendengar, merasa apa yang dilukiskan penyair dalam puisinya. 6) tipografi, tipografi merupakan pembeda penting antara karya puisi dengan prosa dan drama (Waluyo, 1995 : 97). Pada lariklarik puisi tidak membangun periodisitet sebagaimana paragraf dalam karya prosa, tetapi membentuk bait. Baris-baris puisi tidak bermula dari tepi kiri dan berakhir pada tepi kanan. Tepi kiri dan kanan dari halaman yang memuat puisi belum tentu terpenuhi tulisan, dan hal ini tidak berlaku dalam tulisan berbentuk prosa.

Itulah sebabnya seorang penulis puisi harus mempertimbangan dengan baik unsurunsur pembentuk puisi tersebut. Oleh karena itu, para penulis puisi pemula diharuskan melatih diri untuk menggunakan unsur-unsur pembentuk puisi tersebut, sehingga kelak jika ia telah benar-benar menjadi penyair maka menjadi seorang penyair yang mumpuni.

\section{Konsep Pembelajaran Puisi}

Dalam pembelajaran menulis puisi, guru dituntut tidak hanya memberikan teori, tetapi juga membawa siswa untuk terlibat dalam kegiatan menulis secara langsung dan berdiskusi antarteman untuk menyampaikan ide kreatifnya. Hal inilah yang menjadi ukuran belajar siswa dalam menulis puisi. Hal itu dapat sekaligus merefleksikan diri anak atas pengalaman imajinasi yang dirasakan.

Unsur menulis puisi menurut Setyaningsih (2010 : 8) ada enam macam, yakni: penulis, ide yang disampaikan, bahasa, pembaca sasaran, tujuan, dan interaksi antara penulis dengan pembaca melalui tulisan tersebut. Dalam proses pembelajaran dapat dimulai dari siswa mengenali dan berinteraksi dengan lingkungan. Hal itu tentu dimaksudkan sebagai bentuk motivasi diri terhadap hasil karya yang dibawakan, bisa dari pengalaman dengan keluarga, dan lingkungan sosial tempat tinggal. Oleh karena itu, seorang guru sastra yang mendalami tentang puisi maka ia dituntut memiliki banyak ide untuk memunculkan semangat, sebab alam yang membentang adalah wahana inspirasi yang luas bagi siswa.

\section{Media Pembelajaran Kumpulan Film Pendek}

Kumpulan film pendek bertema pandemi dijadikan sebagai media pembelajaran menulis puisi. Hal itu dimaksudkan agar siswa dapat menginspirasi isi film sebagai bahan menulis puisi. Guru menjadi fasilitator pembelajaran sekaligus memberi relaksasi psikologi berupa ketenangan dan kenyamanan belajar. Dalam pembelajaran puisi, yang diamati oleh guru adalah penggunaan diksi, ketepatan gaya bahasa, dan hasil menulis puisi siswa. Berkaitan dengan hasil menulis puisi, fokus guru ditujukan pada penetapan tema puisi yang ditulis, imaji yang muncul, gaya bahasa, rima, dan amanat.

Media film dapat membuat siswa terpengaruh baik secara personal maupun sosial. Secara umum pembelajaran dengan menggunakan media audiovisual atau film lebih mudah membuat siswa meniru dan memahami materi yang disampaikan guru (Dewi dan Budiana, 2018 : 131). Dengan demikian pembelajaran menulis puisi melalui media kumpulan film pendek bertema pandemi dapat mendorong dan membangkitkan minat siswa dalam mengesplor imajinasinya. 
Kegiatannya, guru mengajak siswa untuk melihat film, lalu setelahnya siswa dapat merenungi kesan dan pesan yang ditangkap. Dilanjutkan guru meminta siswa untuk menulis puisi dengan tema yang dipilih sesuai dengan kesan siswa terhadap hasil perenungan setelah menyaksikan pemutaran kumpulan film pendek bertema pandemi tersebut.

Dalam situasi pandemi, pembelajaran dilakukan secara daring, sehingga memungkinkan siswa dengan nyaman meyaksikan pemutaran film tersebut sesuai dengan selera belajar yang mereka inginkan.

\section{METODE PENELITIAN}

Penelitian ini menggunaan metode penelitian tindakan kelas (PTK) dengan menerapkan media kumpulan film pendek bertema pandemi.

Sumber data penelitian ini adalah siswa kelas 1 Bahasa SMAN 1 Krian kabupaten Sidoarjo berjumlah 26 orang siswa, sedangkan data penelitian ini adalah keterampilan siswa menulis puisi berdasarkan unsur pembentuk puisi. Data tersebut diambil melalui penugasan. Adapun data hasil observasi kegiatan guru diambil saat proses pembelajaran berlangsung melalui lembar observasi yang telah disusun.

Data hasil keterampilan menulis puisi dianalisis secara kualitatif berdasarkan kesesuaian tema, latar, gaya bahasa, amanat/pesan, dan tujuan. Sedangkan data hasil observasi dianalisis secara kualitatif berdasarkan kelemahan atau kekurangan yang muncul pada setiap siklus sebagai dasar penetapan tindakan berikutnya.

Prosedur PTK meliputi: perencanaan, pelaksanaan, observasi dan refleksi. Keempat kegiatan tersebut dilakukan dalam satu putaran atau yang disebut siklus. Secara faktual prosedur PTK dapat dilihat dalam gambar alur siklus PTK sebagai berikut.

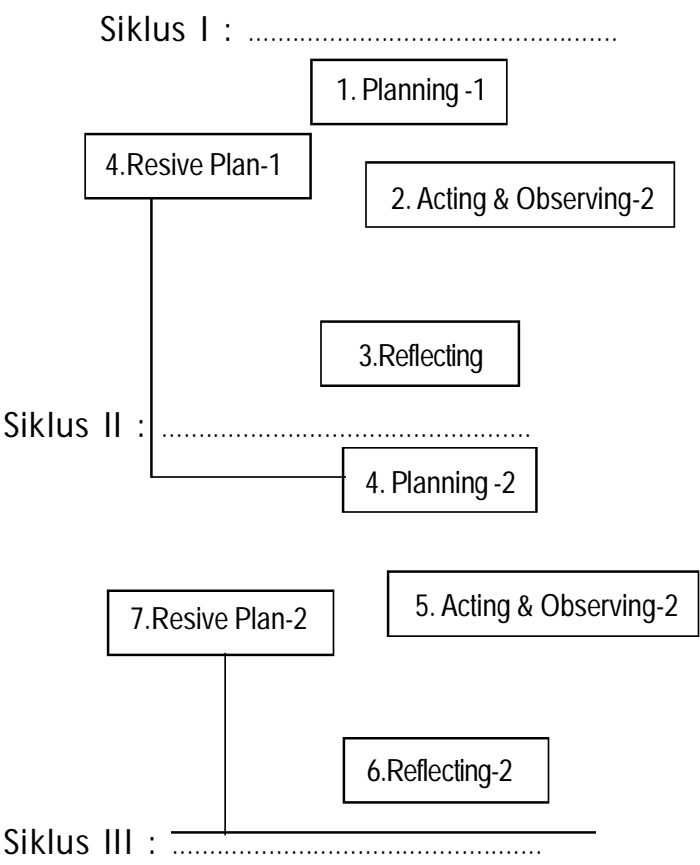

Gambar 1: Alur siklus PTK model Kemmis dan Mc Taggart (Akbar, 2008:86).

Adapun uraian kegiatan adalah sebagai berikut.

\section{Perencanaan}

Sebelum melaksanakan PTK, peneliti merencanakan kegiatan pembelajaran berdasarkan kompetensi dasar yang telah ditetapkan. Perencanaan pembelajaran tersebut meliputi: [1] penyusunan rencana pelaksanaan pembelajaran (RPP) yang berisi langkah-langkah kegiatan mulai dari kegiatan pendahuluan, inti, dan penutup; [2] menyiapkan pembelajaran menggunakan media kumpulan film pendek bertema pandemi yang sudah disesuaikan dengan materi; [3] menyiapkan soal tes berupa penugasan kepada siswa untuk menulis puisi setelah melihat tayangan film pendek bertema pandemi; dan [4] menyiapkan lembar observasi kegiatan guru, serta angket respon siswa.

\section{Pelaksanaan}

Melaksanakan proses pembelajaran dengan menerapkan media kumpulan film pendek bertema pandemi sesuai dengan rencana yang telah ditetapkan. Adapun proses pembelajaran dilakukan dalam tahapan sebagai berikut. Pertama, guru menjelaskan langkah-langkah pembelajaran. Kedua; guru memberikan materi seputar puisi dan unsur-unsur pembentuk puisi. Ketiga guru 
memutarkan film pendek bertema pandemi kepada siswa untuk disimak, dicermati, dan direnungi. Keempat, guru meminta kepada siswa untuk merenungi atau menginspirasi hasil menyaksikan pemutaran kumpulan film pendek tersebut; Kelima, guru meminta siswa menulis puisi berdasarkan hasil inspirasi dari penayangan film pendek tersebut; Keenam, guru meminta siswa untuk mengumpulkan hasil menulis puisi yang telah ditulis tersebut.

\section{Observasi}

Kegiatan observasi ini dilakukan pada saat proses pembelajaran berlangsung. Observasi dilakukan untuk melihat secara langsung kegiatan guru melalui lembar observasi yang telah disiapkan.

\section{Refleksi}

Kegiatan refleksi dilakukan untuk memberikan umpan-balik atas kekurangan atau kelemahan yang dilakukan selama proses pembelajaran berlangsung. Temuan penelitian tersebut menjadi dasar perbaikan pada siklus berikutnya.

\section{HASIL DAN PEMBAHASAN}

Hasil Keterampilan Menulis Puisi Siswa pada Siklus I

Proses pembelajaran siklus I berjalan sebagaimana yang direncanakan. Secara umum dari 26 siswa kelas 1 Bahasa SMAN 1 Krian kabupaten Sidoarjo yang mendapat nilai di bawah ketuntasan masih cukup tinggi. Terdapat 15 orang siswa atau 57,69\% memperoleh nilai di bawah KKM, sedangkan 11 orang siswa atau $42,30 \%$ telah mencapai nilai standard KKM. Hasil tersebut dapat dilihat pada diagram ketuntasan belajar sebagai berikut.

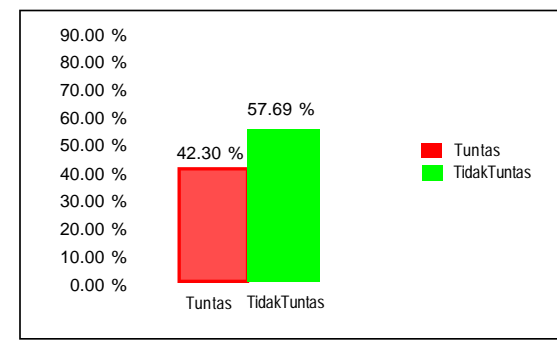

Diagram 1: Nilai Ketuntasan Keterampilan Menulis Puisi pada Siklus I
Klasifikasikan dari hasil tersebut adalah sebagai berikut. Dari 26 orang siswa kemampuan menentukan tema pada kreteria kurang terdapat 7 orang siswa atau 26,92\%, kreteria cukup terdapat 7 orang siswa atau 26,92\%, kreteria baik terdapat 7 orang siswa atau 29,92 \%, dan kreteria sangat baik terdapat 5 orang siswa atau $19,23 \%$. Kemampuan menulis rima pada kreteria kurang terdapat 9 orang siswa atau 34,61 \%, kreteria cukup terdapat 7 orang siswa atau $29,92 \%$, kreteria baik terdapat 6 orang siswa atau $23,07 \%$, dan kreteria sangat baik terdapat 4 orang siswa atau 15,38 \%. Kemampuan menetapkan latar pada kreteria kurang terdapat 6 orang siswa atau 23,07\%, kreteria cukup terdapat 7 orang siswa atau $26,92 \%$, kreteria baik terdapat 8 orang siswa atau 30,76\%, dan kreteria sangat baik terdapat 5 orang siswa atau 19,23\%. Kemampuan meghadirkan majas pada kreteria kurang terdapat 8 orang siswa atau 30,76\%, kreteria cukup terdapat 8 orang siswa atau 30,76\%, kreteria baik terdapat 7 orang siswa atau 26,92 \%, dan kreteria sangat baik terdapat 7 orang siswa atau $26,92 \%$. Kemampuan menentukan amanat/ pesan pada kreteria kurang terdapat 8 orang siswa atau 30,76\%, kreteria cukup terdapat 9 orang siswa atau $34,61 \%$, kreteria baik terdapat 6 orang siswa atau $23,07 \%$, dan kreteria sangat baik terdapat 4 orang siswa atau 15,38\%.

Data keseluruhan hasil keterampilan menulis pada siklus I ini dapat dilihat pada diagram batang berikut.

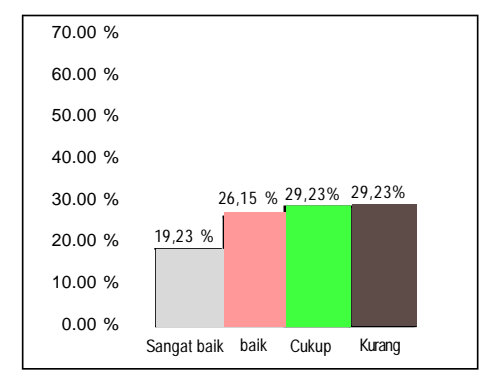

Diagram 2: Hasil Keterampilan Menulis Puisi pada Siklus I

\section{Hasil Observasi Kegiatan Guru pada Siklus I}

Observasi kegiatan guru bertujuan untuk mencari data tentang proses pembelajaran yang dilakukan. Observasi kegiatan guru difokus-kan pada delapan item penilaian, yakni: kemampuan 
melakukan apersepsi, perlakuan pembelajaran, volume suara, penguasaan bahan pembelajaran, strategi bertanya, pemberian balikan (jawaban), penguasaan kelas secara umum, dan pemberian motivasi kepada siswa.

Pada gelar tindakan siklus I ini hasil observasi kegiatan guru dapat diklasifikasi sebagai berikut. Dari 8 item kegiatan guru tersebut, berada dalam kreteria kurang terdapat $25 \%$, kreteria cukup 37,5\%, kreteria baik 37,5\% dan kreteria sangat baik $0 \%$. Dalam diagram batang dapat dilihat sebagai berikut ini.

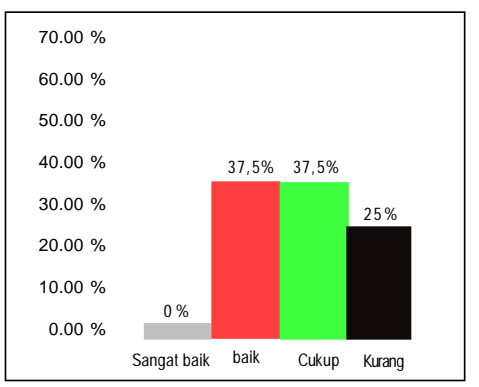

Diagram 3: Hasil Observasi Kegiatan Guru (Peneliti) pada Siklus I

\section{Rangkuman Siklus I}

Pembelajaran siklus I dilaksanakan dalam satu kali pertemuan. Berdasarkan data hasil pembelajaran siklus I tersebut, maka dapat dirangkum sebagai berikut: 1] apersepsi; apersepsi dalam catatan observasi kegiatan guru sudah baik, tetapi masih perlu ditingkatkan, sebab peneliti masih kurang mampu menghubungkan apersepsi dengan materi. Seakan-akan apersepsi berdiri sendiri lepas dari materi; 2] perlakuan pembelajaran; perlakuan pembelajaran yang dimaksud adalah sikap peneliti memperlakukan kondisi pembelajaran. Sudahkah peneliti menempatkan diri sebagai orang tua, sehingga proses pembelajaran berjalan penuh kasih sayang. Hasilnya dianggap cukup. Meskipun demikian tetap perlu ditingkatkan, sebab kegiatan tersebut belum secara mendalam dapat dirasakan dampaknya dan terkesan hanya seperti basa-basi belaka; 3] suara; suara peneliti terasa kurang lancar dan terkadang kurang terdengar. Apalagi pembelajaran daring, jika sinyal internet siswa kurang bagus maka suara tersebut tidak terdengar. Dalam catatan observasi suara dianggap cukup, walaupun demikian masih perlu ditingkatkan agar benar-benar informasi yang disampaikan peneliti dapat didengar dengan jelas oleh siswa; 4] penguasaan bahan pembelajaran; penguasaan bahan pembelajaran dianggap baik. Peneliti telah menyiapkan materi cukup matang, meskipun demikian harus tetap ditingkatkan; 5] strategi bertanya; strategi bertanya masih kurang. Peneliti masih monoton menunjuk siswa yang angkat tangan beraki-kali untuk menjawab pertanyaan yang diutarakan. Padahal, siswa yang tidak angkat tangan belum tentu tidak dapat menjawab. Terkesan peneliti tidak adil dalam; 6] pemberian balikan (jawaban); pemberian balikan atas pertanyaan siswa sudah baik. Peneliti mampu memberikan jawaban atas beberapa pertanyaan siswa, walaupun demikian peneliti harus tetap meningkatkan kemampuan diri; 7]penguasaan kelas; penguasaan kelas sudah cukup. Penilaian cukup tersebut saat pembelajaran secara daring. Pembelajaran daring terkadang suasana kelas tidak terasa gaduh dan ramai; 8] pemberian motivasi; menurut hasil observasi pemberian motivasi masih kurang. Peneliti belum maksimal memotivasi siswa mengikuti pembelajaran. Peneliti terkesan pelit memberikan pujian dan sanjungan. Sebenarnya banyak yang dapat dilakukan oleh guru untuk meningkatkan semangat belajar siswa. Selain memberikan sanjungan dan pujian, guru bisa menarik simpati dengan memberikan hadiah tertentu kepada siswa yang kontributif dalam pembelajaran.

\section{Refleksi Siklus I}

Berdasarkan keseluruhan hasil observasi kegiatan guru dan kegiatan siswa diperoleh suatu kesimpulan sebagai berikut: 1] peneliti masih perlu meningkatkan kemampuan apersepsi; 2] peneliti masih perlu meningkatkan perlakuan pembelajaran; 3] peneliti masih perlu meningkatkan volume suara; 4] peneliti masih perlu meningkatkan penguasaan bahan pembelajaran; 5] peneliti harus memperbaiki dan meningkatkan strategi bertanya kepada siswa; 6] peneliti masih perlu meningkatkan pemberian balikan (jawaban atas pertanyan siswa); 7] peneliti masih perlu meningkatkan penguasaan kelas; dan 8] peneliti harus mem- 
perbaiki dan meningkatkan pemberian motivasi belajar kepada siswa.

Sebagai tindak lanjut dari temuan, peneliti menyiapkan langkah perbaikan pada proses pembelajaran berikutnya.

\section{Hasil Keterampilan Menulis Puisi Siswa pada Siklus II}

Pada siklus II ini hasil keterampilan menulis puisi siswa sangat menggembirakan. Secara umum dari 26 siswa yang mendapat nilai di bawah ketuntasan telah menurun dengan drastis. Hanya terdapat 6 orang siswa atau 23,07 \% memperoleh nilai di bawah KKM, sedangkan 20 orang siswa atau 76,92\% telah mencapai nilai standard KKM yang dicanangkan oleh sekolah. Hasil tersebut dapat dilihat pada diagram ketuntasan belajar sebagai berikut.

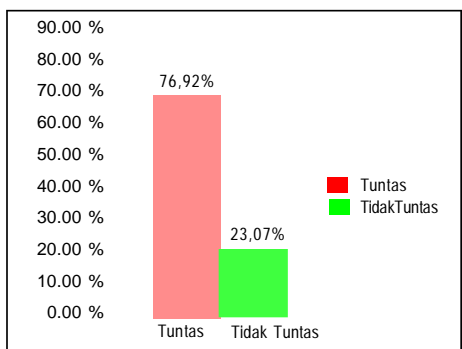

Diagram 4: Nilai Ketuntasan Keterampilan Menulis Puisi pada Siklus II

Klasifikasikan hasil tersebut adalah sebagai berikut. Dari 26 orang siswa kemampuan menentukan tema pada kreteria kurang terdapat 0 orang siswa atau $0 \%$, kreteria cukup terdapat 3 orang siswa atau 11,53\%, kreteria baik terdapat 13 orang siswa atau $50 \%$, dan kreteria sangat baik terdapat 10 orang siswa atau $38,46 \%$. Kemampuan menulis rima pada kreteria kurang terdapat 1 orang siswa atau 3,84\%, kreteria cukup terdapat 4 orang siswa atau $15,38 \%$, kreteria baik terdapat 11 orang siswa atau $42,30 \%$, dan kreteria sangat baik terdapat 10 orang siswa atau 38,46\%. Kemampuan menetapkan latar pada kreteria kurang terdapat 0 orang siswa atau $0 \%$, kreteria cukup terdapat 2 orang siswa atau 7,69\%, kreteria baik terdapat 13 orang siswa atau $50 \%$,, dan kreteria sangat baik terdapat 11 orang siswa atau 42,30\%. Kemampuan meghadirkan majas pada kreteria kurang terdapat 0 orang siswa atau $0 \%$, kreteria cukup terdapat 3 orang siswa atau 11,53\%, kreteria baik terdapat 12 orang siswa atau $46,15 \%$, dan kreteria sangat baik terdapat 11 orang siswa atau 42,30 \%. Kemampuan menentukan amanat/ pesan pada kreteria kurang terdapat 1 orang siswa atau 3,84\%, kreteria cukup terdapat 2 orang siswa atau 7,69\%, kreteria baik terdapat 13 orang siswa atau $50 \%$, dan kreteria sangat baik terdapat 10 orang siswa atau $38,46 \%$.

Keseluruhan proses pembelajaran pada siklus II tersebut dapat disajikan dalam bentuk diagram batang sebagai berikut.

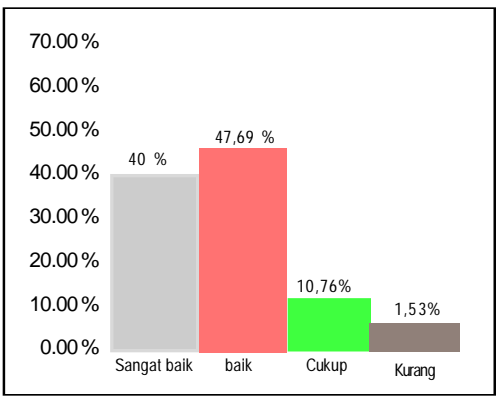

Diagram 5: Hasil Keterampilan Menulis Puisi pada Siklus II

\section{Observasi Kegiatan Guru pada Siklus II}

Perhatian terhadap observasi kegiatan guru pada siklus II ini semakin ditingkatkan. Delapan item penilaian yang tertuang dalam lembar observasi menjadi fokus utama. Hasil observasi kegiatan guru pada siklus I dijadikan dasar dalam gelar tindakan pada siklus II ini.

Dari 8 item kegiatan guru tersebut berada dalam kreteria kurang $0 \%$, kreteria cukup $0 \%$, kreteria baik 37,5\% dan kreteria sangat baik $62,5 \%$.

Secara keseluruhan hasil observasi kegiatan guru dalam proses pembelajaran pada siklus II ini dapat disajikan dalam diagram batang sebagai berikut.

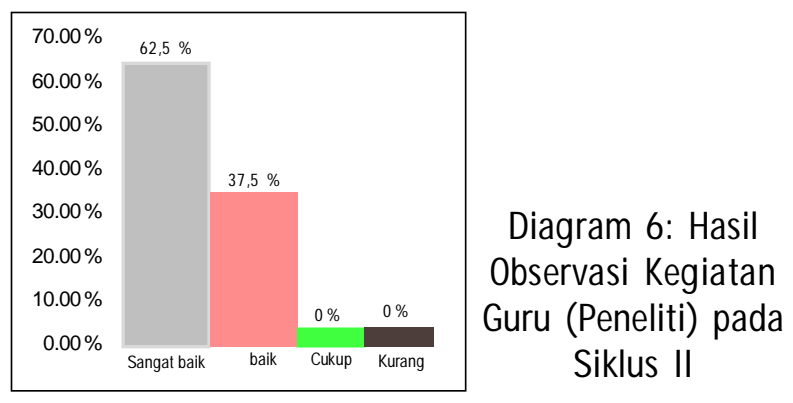




\section{Rangkuman Siklus II}

Pelaksanaan pembelajaran siklus II berjalan sesuai dengan rencana. Dalam catatan lembar observasi dapat dipaparkan hal-hal sebagai berikut: 1] apersepsi; apersepsi dalam catatan observasi sangat baik, peneliti sudah mampu menghubungkan apersepsi dengan materi yang disampaikan; 2] perlakuan pembelajaran; perlakuan pembelajaran sudah baik. Peneliti sudah berupaya maksimal ke arah yang lebih baik. Peneliti juga telah berusaha menempatkan diri sebagai orang tua, sehingga terbentuk kedekatan siswa-guru; 3] suara; suara peneliti dalam proses pembelajaran sudah baik. Volume suara sudah cukup keras, sehingga dapat didengar seluruh siswa; 4] penguasaan bahan pembelajaran; penguasaan bahan pembelajaran sangat baik. Rupanya peneliti benar-benar mempersiapkan bahan pembelajaran dengan matang; 5] strategi bertanya; strategi bertanya sangat baik. Peneliti sudah tidak monoton menunjuk siswa yang berangkat tangan saja, tetapi juga memberi kesempatan siswa yang diam; 6] pemberian balikan (jawaban); pemberian balikan pertanyaan siswa sangat baik. Dengan kesiapan materi yang bagus, peneliti dapat dengan mudah menjawab beberapa pertanyaan siswa; 7] penguasaan kelas; penguasaan kelas sudah baik. Secara umum penguasaan kelas sudah baik, sebab pembelajaran daring jika terjadi komunikasi timbal balik, maka proses pembelajaran sudah dianggap baik. Apalagi gelar tindakan pada siklus II ini suasana kelas nyaman dan penuh kehangatan; 8] pemberian motivasi; menurut hasil observasi pada siklus II pemberia motivasi sangat baik. Berkaca dari kekurangan pada siklus I, maka peneliti mengubah total teknik memberikan motivasi. Hampir setiap siswa yang mampu menjawab pertanyaan diberikan sanjungan dan pujian. Tidak hanya itu, peneliti juga memberikan hadiah kepada siswa yang karyanya terpilih.

\section{Reflesi Siklus II}

Berdasarkan catatan keseluruhan hasil observasi kegiatan guru dan kegiatan siswa di kelas pada siklus II ini, dapat disimpulkan sebagai berikut: 1] berkaitan dengan kegiatan apersepsi, peneliti sudah melakukan kegiatan itu dengan sangat baik; 2] berkaitan dengan perlakuan pembelajaran, peneliti sudah melakukan langkahlangkah tersebut dengan baik; 3] berkaitan dengan suara, peneliti sudah melakukan perbaikan volume suara sehingga terjangkau ke semua siswa dengan baik; 4] berkaitan dengan penguasaan bahan pembelajaran, peneliti sudah meningkatkan penguasaan materi dengan sangat baik; 5] berkaitan dengan strategi bertanya kepada siswa, peneliti sudah melakukan strategi tersebut dengan sangat baik; 6] berkaitan dengan pemberian balikan (jawaban pertanyan siswa), peneliti sudah melakukan dengan sangat baik; 7] berkaitan dengan penguasaan kelas, peneliti telah berhasil mengendalikan kelas dengan baik; 8] berkaitan dengan pemberian motivasi belajar kepada siswa, peneliti sudah mengambil langkah-langkah pemberian motivasi dengan sangat baik.

Dari rangkaian kegiatan tersebut, terdapat satu kelemahan atau kekurangan yang muncul, yakni pengelolalan waktu. Kegiatan Proses pembelajaran yang dilakukan sepuluh menit melewati batas waktu yang telah ditentukan. Namun, hal tersebut tidak terlalu bermasalah, sebab guru mata pelajaran berikutnya tidak masuk karena sakit, sehingga berlebihnya waktu tersebut tidak merugikan guru lain.

Peneliti bersama guru mitra merasa gelar pembelajaran pada siklus II ini berjalan sesuai denga harapan. Meskipun masih ada kekurangan lain, tetapi kekurangan tersebut tidak mempengaruhi terhadap hasil belajar siswa. Oleh karena itu, peneliti bersama guru mitra bersepakat mengakhiri siklus.

\section{Hasil Angket Respon Siswa}

Angket diberikan untuk mendapatkan data respon siswa. Angket respon siswa dibagi dalam empat kategori jawaban, yakni kategori jawaban kurang, kategori jawaban cukup, kategori jawaban baik, dan kategori jawaban sangat baik.

Kategori kurang diberikan apabila proses pembelajaran yang diharapkan oleh siswa tidak terakomodasi dalam kegiatan guru, kategori cukup diberikan apabila proses pembelajaran 
yang diharapkan oleh siswa terakomodasi sebagian dalam kegiatan guru, kategori baik diberikan apabila proses pembelajaran yang diharapkan oleh siswa sudah terakomodasi dalam kegiatan guru, dan kategori sangat baik diberikan apabila proses pembelajaran yang dilakukan oleh guru melampaui apa yang diharapkan oleh siswa.

Berdasarkan tabel respon siswa tersebut pelaksanaan pembelajaran menulis puisi menggunakan media film pendek bertema pandemi selama siklus I dan II dapat dipersentase sebagai berikut. Dari 26 orang siswa menjawab aspek penilaian nomor 1 , pada kreteria kurang terdapat 0 orang siswa atau $0 \%$, kreteria cukup terdapat 7 orang siswa atau $26,92 \%$, kreteria baik terdapat 11 orang siswa atau 42,30\%, dan kreteria sangat baik terdapat 8 orang siswa atau 30,76\%. Siswa menjawab aspek penilaian nomor 2, pada kreteria kurang terdapat 0 orang siswa atau $0 \%$, kreteria cukup terdapat 5 orang siswa atau $19,23 \%$, kreteria baik terdapat 12 orang siswa atau 46,15\%, dan kreteria sangat baik terdapat 9 orang siswa atau 34,61 \%. Siswa menjawab aspek penilaian nomor 3, pada kreteria kurang terdapat 0 orang siswa atau $0 \%$, kreteria cukup terdapat 5 orang siswa atau $19,23 \%$, kreteria baik terdapat 13 orang siswa atau $50 \%$, dan kreteria sangat baik terdapat 8 orang siswa atau $19,23 \%$. Siswa menjawab aspek penilaian nomor 4, pada kreteria kurang terdapat 0 orang siswa atau $0 \%$, kreteria cukup terdapat 5 orang siswa atau $19,23 \%$, kreteria baik terdapat 11 orang siswa atau $42,30 \%$, dan kreteria sangat baik terdapat 10 orang siswa atau 38,46\%. Siswa menjawab aspek penilaian nomor 5, pada kreteria kurang terdapat 0 orang siswa atau $0 \%$, kreteria cukup terdapat 3 orang siswa atau $11,53 \%$, kreteria baik terdapat 12 orang siswa atau 46,15\%, dan kreteria sangat baik terdapat 11 orang siswa atau 42,30\%. Siswa menjawab aspek penilaian nomor 6 , pada kreteria kurang terdapat 0 orang siswa atau $0 \%$, kreteria cukup terdapat 6 orang siswa atau 23,07\%, kreteria baik terdapat 9 orang siswa atau $34,61 \%$, dan kreteria sangat baik terdapat 12 orang siswa atau 46,15\%. Siswa menjawab aspek penilaian nomor 7, pada kreteria kurang terdapat 0 orang siswa atau $0 \%$, kreteria cukup terdapat 5 orang siswa atau 19,23\%, kreteria baik terdapat 10 orang siswa atau 38,46\%, dan kreteria sangat baik terdapat 11 orang siswa atau 42,30\%. Siswa menjawab aspek penilaian nomor 8, pada kreteria kurang terdapat 0 orang siswa atau $0 \%$, kreteria cukup terdapat 2 orang siswa atau $7,69 \%$, kreteria baik terdapat 11 orang siswa atau $42,30 \%$, dan kreteria sangat baik terdapat 13 orang siswa atau $50 \%$. Siswa menjawab aspek penilaian nomor 9, pada kreteria kurang terdapat 0 orang siswa atau $0 \%$, kreteria cukup terdapat 5 orang siswa atau 19,23\%, kreteria baik terdapat 6 orang siswa atau 23,07\%, dan kreteria sangat baik terdapat 15 orang siswa atau 57,69 \%, dan siswa menjawab aspek penilaian nomor 10 , pada kreteria kurang terdapat 0 orang siswa atau $0 \%$, kreteria cukup terdapat 7 orang siswa atau 26,92\%, kreteria baik terdapat 11 orang siswa atau 42,30\%, dan kreteria sangat baik terdapat 8 orang siswa atau $30,76 \%$

Untuk mengetahui penyebaran angket respon siswa tersebut dapat dilihat dalam diagram berikut.

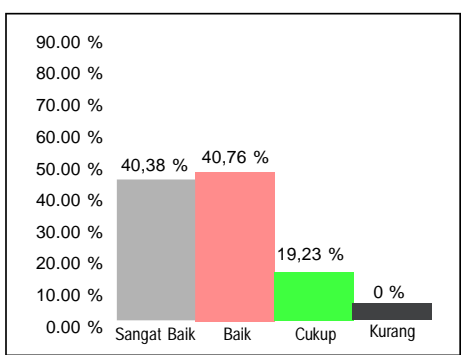

Diagram 7: Hasil Penyebaran Angket Respon Siswa

\section{Pembahasan}

Penelitian ini diawali dari studi pendahuluan untuk mencari informasi berkaitan dengan penggunaan media pembelajaran sebagai pendukung proses pembelajaran terutama pada kompetensi dasar (KD) 48 (menulis puisi).

Hasil penggalian informasi diperoleh data bahwa secara umum kemampuan menulis puisi pada siswa kelas 1 Bahasa SMA Negeri 1 Krian kabupaten Sidoarjo masih rendah. Rendahnya kemampuan menulis puisi siswa disebakan oleh 
guru mitra kesulitan memilih dan memanfaatkan media pembelajaran yang tepat, serta adanya kendala waktu oleh tugas administrasi keseharian. Selain itu, pembelajaran secara daring juga menjadi faktor penyebab lain, meskipun keadaan tersebut tidak diberlakukan untuk semua daerah di Indonesia (Widiastutik, 2021 : 35). Namun, upaya memilihan strategi yang tepat untuk menyukseskan progam belajar dari rumah (BDR) mutlak diperlukan (Kurniasari, 2020 : 23). Pademi covid 19 memang memaksa kita untuk melakukan pembelajaran dari rumah, mau atau tidak mau, dan suka atau tidak suka (Khusniyah, 2020 : 6).

Pada mata pelajaran Bahasa Indonesia SMA Negeri 1 Krian kabupaten Sidoarjo menetapkan kriteria ketuntasan minimal (KKM) berada pada angka 75. Secara umum nilai siswa kelas 1 Bahasa pada pembelajaran KD 48 menulis puisi rata-rata adalah 60 . Melalui hasil penghitungan tingkat ketuntasan belajar, diperoleh data terdapat $65,38 \%$ siswa dinyatakan tidak tuntas, dan 34,61 \% dinyatakan tuntas. Hasil tersebut menunjukkan kegagalan yang cukup tinggi, terutama pembelajaran yang dilakukan saat masa pandemi ini.

Hasil studi pendahuluan ini menjadi data penting bagi peneliti untuk melangkah lebih lanjut. Data hasil studi pendahuluan yang cukup komprehensif ini membuat peneliti memutuskan untuk tidak melakukan pembuktian ulang dengan melakukan kegiatan prasiklus.

Berangkat dari perolehan data tersebut peneliti menyusun rencana pembelajaran keterampilan menulis puisi melalui media kumpulan film pendek bertema pandemi. Hal ini sejalan dengan pendapat Handayani (2006 : 12) bahwa media film dapat mengatasi keterbatasan indera terutama penglihatan, merasang dan menarik minat, serta memikat perhatian siswa. Demikian pula Dewi dan Budiana (2018 : 129) mengatakan bahwa film sebagai alat penyampai pesan dan memiliki pengaruh yang besar terhadap khalayak terutama siswa di kelas.

Hasil gelar tindakan pada siklus I ini tingkat ketuntasan belajar dari 26 yang hadir terdapat 57,69 \% siswa dinyatakan tindak tuntas, dan hanya $42,30 \%$ siswa dinyatakan tuntas.
Demikian pula hasil observasi kegiatan guru pada siklus I dari delapan item kegiatan guru tersebut berada dalam kreteria kurang terdapat $25 \%$, kreteria cukup 37,5\%, kreteria baik $37,5 \%$ dan kreteria sangat baik $0 \%$. Dari rangkuman pelaksanaan pembelajaran pada siklus I ini secara umum hasil yang diperoleh masih belum mencapai harapan. Oleh karena itu, peneliti bersama guru mitra menyiapkan tindak lanjut.

Semua kelemahan atau kekurangan pada siklus I direfleksi kembali pada gelar tindakan siklus II. Hasil pelaksanaan pembelajaran siklus II tingkat ketuntasan belajar dari 26 siswa yang dinyatakan tindak tuntas terdapat $23,07 \%$, sedangkan yang dinyatakan tuntas $76,92 \%$ siswa. Sementara itu, hasil observasi kegiatan guru pada siklus II dari delapan item kegiatan guru tersebut terdapat $0 \%$ kreteria kurang, $0 \%$ kreteria cukup, 37,5\% kreteria baik, dan $62,5 \%$ berada pada kreteria sangat baik $0 \%$. Meskipun pada siklus II ini masih ada kekurangan atau kelemahan, tetapi tidak berpengaruh terhadap hasil belajar siswa.

Berdasarkan hasil tersebut maka pelaksanaan pembelajaran menulis puisi melalui media kumpulan film pendek bertema pandemi dianggap telah berhasil. Peneliti bersama guru mitra memutuskan untuk tidak perlu melakukan siklus berikutnya. Secara umum keberhasilan tersebut karena upaya cermat peneliti memperbaiki setiap kelemahan atau kekurangan yang diperoleh dari setiap siklus.

Hasil penelitian ini sejalan dengan penelitianpenelitian sebelumnya yang sama-sama menggunakan media film. Bahwa, media film, terutama film pendek bertema pandemi, efektif dan mampu membangkitkan semangat belajar serta dapat mengangkat hasil belajar siswa.

Langkah terakhir adalah menyebar angket untuk mengetahui respon siswa. Angket disebarkan kepada siswa pada saat semua rangkaian siklus berakhir.

Hasil angket menunjukkan bahwa siswa yang memberikan apresiasi positif terhadap pembelajaran melalui media kumpulan film pendek bertema pandemi cukup tinggi. Dari 
empat kriteria penilaian, terdapat $0 \%$ siswa menilai kurang, 38,46 \% cukup, $81,53 \%$ baik, dan $80,76 \%$ sangat baik.

\section{SIMPULAN dan REKOMENDASI}

1. Pembelajaran menulis puisi melalui media kumpulan film pendek bertema pandemi dilaksanakan melalui 2 siklus.

2. Hasil pembelajaran meningkat dilihat dari ketuntasan belajar dari $42,30 \%$ pada siklus I menjadi 76,92 \% pada siklus II.

Atas dasar hasil tersebut peneliti merekomendasikan kepada: 1] guru untuk menjadikan media tersebut sebagai alternatif media pembelajaran menulis puisi; 2] kepala sekolah sebagai masukan berharga dalam rangka menetapkan kebijakan terkait dengan teknis pembelajaran untuk memperbaiki dan meningkatkan sistem pembelajaran. $[\alpha]$

\section{DAFTAR PUSTAKA}

Akbar, Sa'dun. 2008. Penelitian Tindakan Kelas: Filosofi, Metodologi, Implementasi. Yogyakarta: Cipta Media. Dewi, Putri Kumala dan Nia Budiana. 2018. Media Pembelajaran Bahasa: Aplikasi Teori dan Strategi Pengoptimalan Pembelajaran. Malang: UB Press.

Elisa, Meli. 2017. Peningkatan Menulis Puisi dengan Menggunakan Media Film Dokumenter (Penelitian Tindakan Kelas Terhadap Siswa Kelas VIII C MTs Al Islah, Karangmulya, Jamanis, Tasikmalaya). Jurnal Diksatrasia ISSN: 2089-3027, Vol. 1, No.2.

Hidayati, Ririn Eva. 2021. Efektivitas Pembelajaran Daring Menggunakan E-Learning Madrasah di Masa Covid 19. Jurnal Inovasi ISSN: 1978-4953/ E-ISSN:2746-6450, Vol.15, No.1. https:// doi. org/10.52048/ inovasi.v15i1. 185

Handayani, Muslih Aris. 2006. Studi Peran Film Dalam Dunia Pendidikan. Jurnal INSANIA ISSN: 1410-0053 / E-2598-3091, Vol. 11, No.2.

Kurniasari, A, Pribowo F.S.P, dan Putra D.A. 2020. Analisis Efektivitas Pelaksanaan Belajar dari Rumah (BDR) Selama Pandemi Covid 19. Jurnal Review Pendidikan dasar: Jurnal Kajian Pendidikan dan Hasil penelitian, $6(3)$, pp. 1-8.

Khusniyah, N. L dan Hakim L. 2019. Efektivitas Pembelajaran Berbasis Daring: Sebuah Bukti pada Pembelajaran Bahasa Inggris. Jurnal Tatsqif, 17(1),pp. 74-83.

Setyaningsih. 2010. Penerapan Metode Field Trip Untuk Meningkatkan Kemampuan Menulis Puisi Pada siswa Kelas VII B SMP Bhineka Karya Boyolali Tahun Ajaran 2009/2010. Skripsi. Program Studi Pendidikan Bahasa dan Sastra Indonesia FKIP Universitas Sebelas Maret Surakarta.

Warsiman. 2016. Membumikan Pembelajaran Sastra Yang Humanis. Malang. Penerbit: UB Press.

Warsiman. 2017. Pengantar Pembelajaran Sastra: Sajian dan Kajian Hasil Riset. Malang. Penerbit: UB Press. Widiatutik, Trisya. 2021. Pengembangan E-Modul Bahasa Indonesia Kelas XII dengan Flip PDF Profesional sebagai Alternati Pembelajaran di Tengah Pandemi Covid 19. Jurnal Inovasi ISSN:1978-4953/ E-ISSN:27466450, Volume 15, No. 1. https:// doi.org/ 10.52048/inovasi.v15i1.211

Waluyo, J H. 1995. Teori dan Apresisasi Puisi. Surakarta: PT. Gelora Aksara Pratama. 